\title{
SOLAR ACTIVITY AND COSMIC RAY INFLUENCE ON CLIMATE
}

\author{
Chapanov Ya. ${ }^{1}$, Gorshkov V. ${ }^{2}$ \\ ${ }^{l}$ National Institute of Geophysics, Geodesy and Geography, BAS, Sofia, Bulgaria \\ E-mail: yavor.chapanov@gmail.com \\ ${ }^{2}$ Pulkovo Observatory, RAS, St. Petersburg, Russia \\ E-mail: vigor@gaoran.ru
}

\section{ВЛИЯНИЕ СОЛНЕЧНОЙ АКТИВНОСТИ И КОСМИЧЕСКИХ ЛУЧЕЙ НА КЛИМАТ}

\begin{abstract}
Чапанов Я. ${ }^{1}$, Горшков В. ${ }^{2}$
${ }^{1}$ Национальный Институт Геофизики, Геодезии и Географии БАН, София, Болгария ${ }^{2}$ Главная (Пулковская) астрономическая обсерватория РАН, Санкт-Петербург, Россия

Циклы солнечной активности влияют на различные климатические параметры дожди, снежные покровы, речные потоки и другие гидрологические ичиклы. Эти процессы обусловлены главным образом вариациями полного солнечного облучения (TSI), за которыми следуют изменения погоды и климата. Недавно был обнаружен новый механизм модуляичи климата, основанный на изменениях потока космических лучей (CR). Этот механизм объясняет ичепные процессьы, возникающие при модуляции CR гелиосферой и геомагнитным полем, за которым следует производство озона в тропопаузе и изменение содержания воды. Атмосферная вода является самым мощңным парниковым газом, и ее изменения приводят к значительным изменениям температуры. Взаимосвязь между солнечными ииклами, с одной стороны, и температурой и изменением осадков в Северо-Восточной Европе, с другой стороны, исследуется с помошью восстановленных TSI и CR за период 1766-2000 г2. Временные ряды анализируются методом частичной аппроксимачии Фурье (PFA) и сингулярным спектральным анализом (SSA). Колебания CR, солнечных и климатических индексов имеют некоторые общие долгопериодические ичкль. Обсуждается возможность создания долгосрочных моделей прогноза, основанных на цииклах солнечной активности.
\end{abstract}

\section{DOI: 10.31725/0552-5829-2018-401-404}

The solar activity affects all geosystems, including climate and weather. The TSI cycles are the main source of climate indices variations. Recently Kilifarska [1] proposed a new mechanism of climate modulation, based on cosmic ray variations. This mechanism is based on chain processes near tropopause by ozone production, temperature variations, followed by vertical winds and water content change. The last step of this chain affects strongly surface temperature, because the atmospheric water is one of the most powerful greenhouse gas. This model provides an explanation for the cascade processes in which CR, whose total energy is relatively small, cause climatic effects with much more energy. The solar activity cycles modulate CR directly by the heliosphere and indirectly by the geomagnetic field changes, whose effect is visible mainly at high latitudes. 
To study solar and CR influence on climate, three different latitude areas of North-Eastern Europe are chosen (Fig. 1a). The precipitation and temperature for the period 1767-2000 are determined from data grids $\left(0.5^{\circ} \times 0.5^{\circ}\right)$ [2]. The monthly temperature and precipitation are averaged from their gridded values by the robust Danish Method. The estimated TSI for the last 400 years are based on the NRLTSI2 historical TSI reconstruction model by Lean [3]. Using reconstructed magnetic flux by Solanki et al. [4] as an input to a spherically symmetric quasi-steady state model of the heliosphere, Usoskin [5] calculate the intensity of galactic cosmic rays at the Earth's orbit since 1610 .

The FFT spectra of temperature from different latitude zones have common cycles, while the precipitation spectra are almost coherent for Zone 2 and 3, and significant different for Zone 1. So, the precipitation data from different zones are suitable to determine latitudinal dependence of $\mathrm{CR}$ influences on climate variations. The trend of principal components $(p c)$ by SSA decomposition of temperature and precipitation series dominate after annual one (Fig. 1b). These components especially for precipitation have strong latitude increasing of trend rice after $1950^{\text {th }}$. The second after these components low frequency $p c$ is also shown in Fig. 1b.
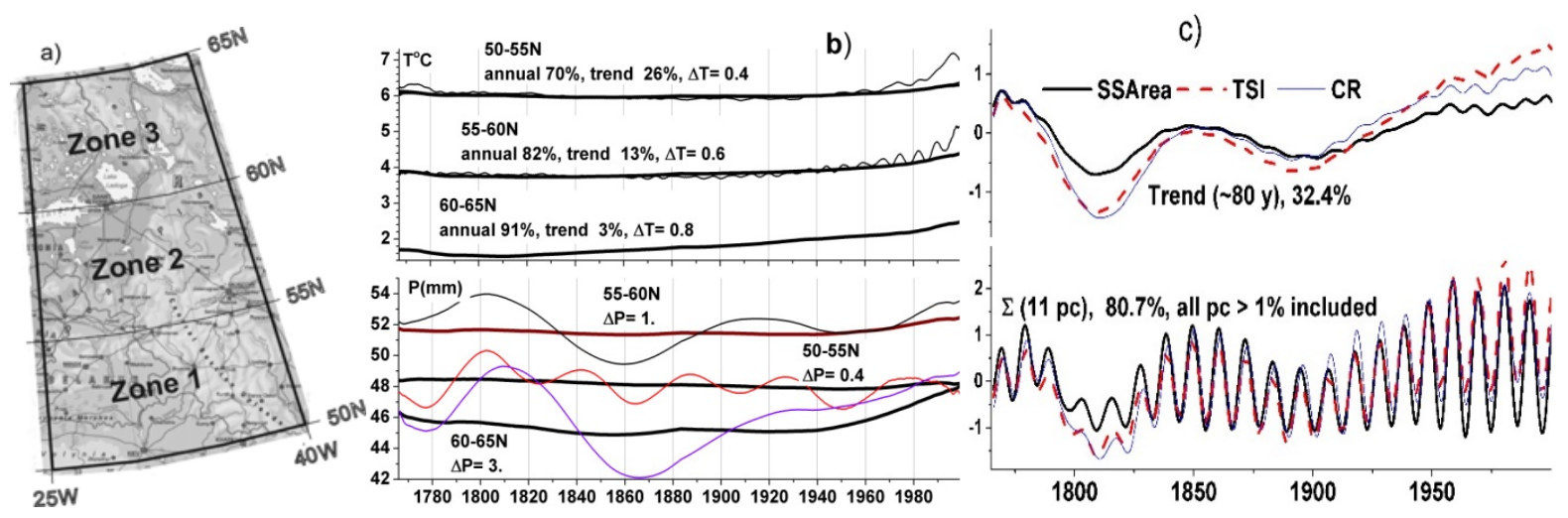

Fig. 1.

The TSI, Sunspot Area and CR (inverted) data are highly correlated in wide spectrum bands. Their influence on climate variation is rather similar that is confirmed by multivariate SSA (MSSA), described in [6]. The 11-year solar cycle dominate in common variations ( $\sim 50 \%$ of series power) and other trend and long periodic terms put together with main cycle almost $81 \%$ (Fig. 1c).

It is obvious common increase in the end of 20 century as solar activity as temperature and precipitation. However, the lack of precipitation and temperature data for 21 century could not assert that the solar activity is the reason of these climatic changes because the last solar circles in 21 century are more weak then previous ones.

The common solar, space and earth cycles are determined by the PFA method described in [7]. The PFA provides Least Squares estimate of the harmonically coefficients with average accuracy around $0.1 \mathrm{mw} / \mathrm{m}^{2}$ for TSI; $10^{-5}$ 
for CR; $0.3 \mathrm{~mm}$ for precipitation and $0.3^{\circ} \mathrm{C}$ for temperature. The PFA calculated common cycles are shown in Figs. 2-4, where the bold lines represent TSI or CR oscillations and the dashed lines represent the climate oscillations from Zone 3.
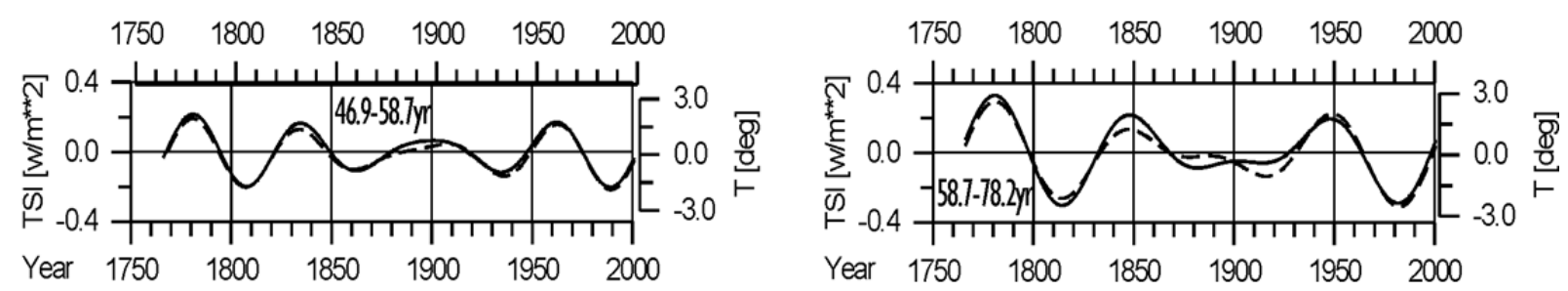

Fig. 2.
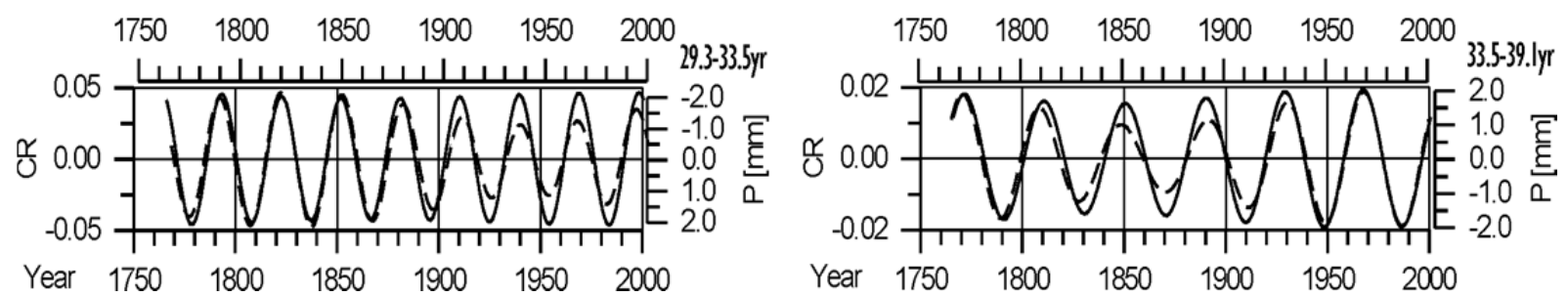

Fig. 3.
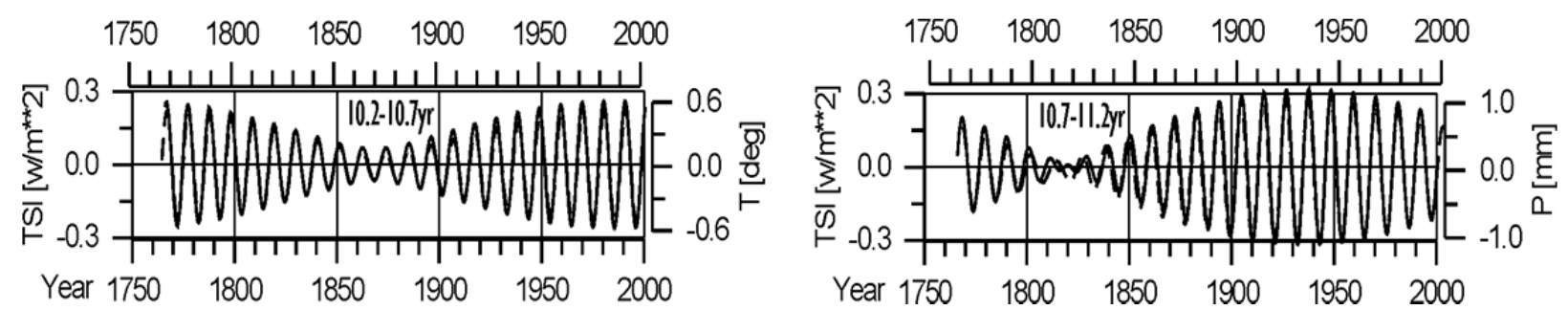

Fig. 4.

The TSI influence on climate is stronger than the CR influence with exception the oscillations with period around 20 year and from period band 35-45 years. The long-term variations of temperature with periodicity above 47 years have excellent agreement with TSI harmonics (Fig. 2). The CR oscillations with periods 29-39 years dominate on precipitation variations (Fig. 3), where the precipitation decreases synchronous with CR cycles in periodicity band 29-33 years and increases in band 33-39 years. An excellent agreement exists between TSI and climate oscillations with periods close to the Schwabe cycle (Fig. 4), where the graph lines cover each other.

The result of common MSSA decomposition of cosmic and climatic series are shown in Fig. 5. The data have to be standardized $\left(y_{i}=\left(x_{i}-\right.\right.$ mean $\left.) / \sigma\right)$ in the MSSA case for scaling. The most power annual components were excluded from common $p c$ as they are absent in cosmic series. The next power component are the Schwabe cycle as it is in PFA. However, all other $p c$ revealed by PFA besides very long-periodic ones (more than 80 years with $15-25 \%$ contribution 
in series power) have a small power (less $1 \%$ of whole series power) and nonstationary shape.

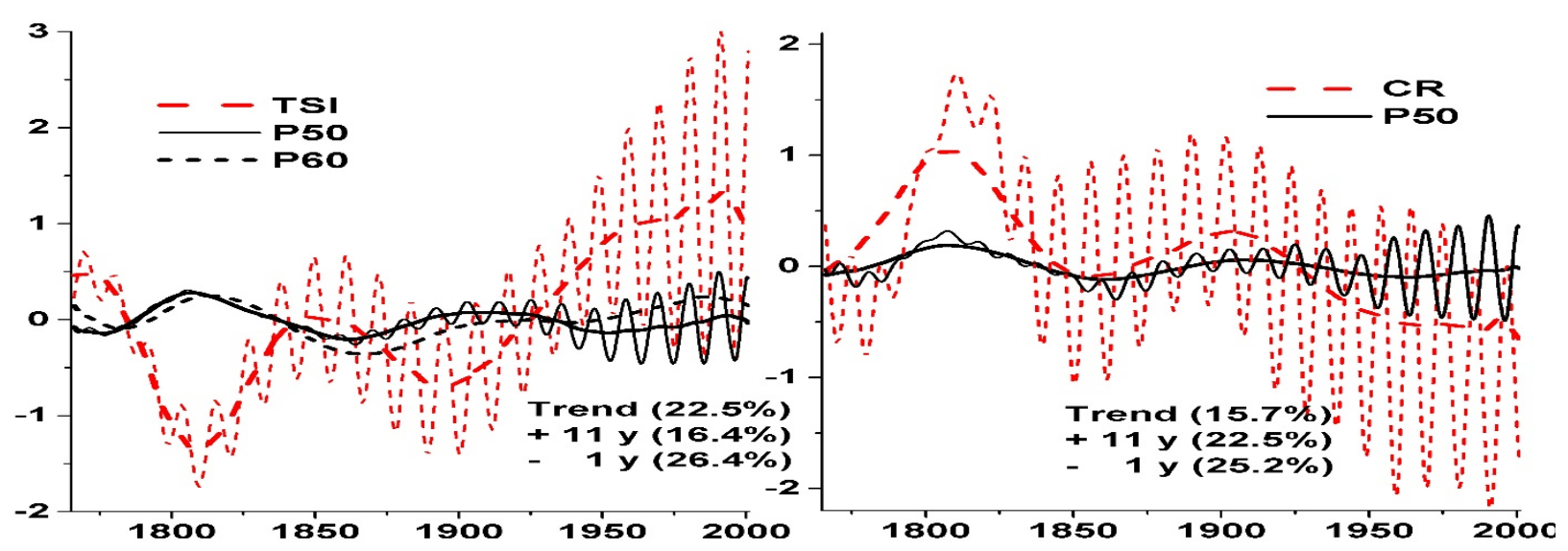

Fig. 5.

In conclusions, the TSI and CR harmonics drive wide spectrum of climate oscillations especially observable in the long periodic and eleven-year solar cycle. The CR influence on climate is stronger on high latitudes, especially on precipitation over $55^{\circ}-65^{\circ} \mathrm{N}$ latitudes and less on temperature. The TSI harmonics provide warming cycles, while CR harmonics provide cooling cycles, whose common effect is often visible as short-time phase reverse.

The decadal and long-periodic solar activity variations play important role in the observed variations of climate indices, mean sea level, glacier thickness and water content. Their study may help better understanding of recent climate changes after addition of climatic data of 21 century. The new model of solarterrestrial influences, based on solar harmonics, may improve our predictions of danger climate events during this century.

\section{References}

1. Kilifarska, N.A., Tassev, Y.K. and Tomova, D.Y. // Sun and Geosphere, 2008, 3, 1, 10-17.

2. Casty, C., Handorf, D. and M. Sempf// Geophysical Research Letters, 2005, 32, 13.

3. Lean, J. // Geophys. Res. Lett., 2016, Vol. 27, No. 16, 2425-2428.

4. Solanki, S. K., Sc ̈̈ussler, M., and Fligge, M. // Nature, 2000, 480, 445-446.

5. Usoskin, I.G., K. Alanko-Huotari, G.A. Kovaltsov, K. Mursula // JGR, 2005, 110(A12), A12108.

6. Goliandina N., Korobeynikov, A., Zhigljavsky A., Singular Spectrum Analysis with R, Springer, p. 272, 2018.

7. Chapanov Y., Ron C., Vondrk J. // Acta Geodyn.Geomater., 2017, 14, No. 2 (186), 241250. 